\title{
Major Socio-Economic Factors Responsible for Crimes
}

\author{
Naseer Ahmad ${ }^{* 1}$ and Mirza Adnan Asim ${ }^{2}$ \\ ${ }^{1}$ Department of Sociology BZU, Bahadur Sb-Campus Layyah, \\ ${ }^{2}$ Department of Sociology, University of Sargodha \\ *Corresponding Author: naseerlssa2@gmail.com
}

\begin{abstract}
Crime in Pakistan has been increasing day by day with the passage of time. This research discussed two particularly influential approaches to the explanation of the role of Socio-Economic factors that are responsible for crimes. One of these approaches emphasizes social orientations and the other economic deprivation. Certain groups allegedly endorse values that are supportive of criminal behavior. In this study Quantitative research method is used and universe of this study is district jail Sargodha. Data is collected through questionnaire and 110 respondents included in this study which is selected after applying simple random sampling technique and through SPSS (statistical packages for social sciences) data analysis is comprises. Even though statistical significance is often difficult and problematic but this technique is used to logically and scientifically approve the factors including social and economic which create a sense of disturbance and responsible for creating the rebellion traits in that individual. These result shows crimes have directed attention to poverty, injustice, unemployment, lawlessness, anomic situation, general economic inequality, and inequality. So socio-economic factors often present and held responsible behind every criminal act that is done by a human. Now as the result the people chose the path of crime that satisfied and pulled out him from the tense situation temporarily but they have to pay the consequences of their criminal actions in the form of a few year prison in corresponding to a small type of crime and sometimes its declared as a lifetime time prison and death penalty according to the severity and intensity of crime.
\end{abstract}

Keywords: Crimes, Socio-Economic determinants, Illiteracy, Poverty

\section{Introduction}

Crimes have always plagued every society in human history. The history of crime is as old as history of mankind. The first crime was committed by Cain, the first son of Adam and Eve, when he murdered his brother Abel out of jealousy. Crime is the breaking of rules or laws for which 
some governing authority can ultimately prescribe a conviction. While every crime violates the law, not every violation of the law counts as a crime.

Crime is a major source of insecurity and discomfort in every society. There is no doubt that crime inflicts enormous monetary and psychological costs on society. The act of criminality gives rise to the feeling of insecurity and fear to those who have not been a victim as well. This sense of panic of being victimized generates negative effects on wellbeing. A majority of the society members suffers from the side effects of crimes (Logan, 1994).

There are many factors, Joblessness, high inflation, illiteracy, backwardness, local disputes, political rivalry, urban density, cultural variations and religious intolerance which are compelling people to commit crimes. Continuous failure in education, longer unemployment and disgrace by family members put the youth in conditions where they develop a strong desire for immediate success. Sensing failure and contempt, they develop criminal behavior by rejecting meritocratic ideology (Cloward and Ohlin, 1960).

The last five years of democratic government have seen a phenomenal rise in heinous crimes all over Pakistan as the rulers in general have been busy in loot and plunder of the national wealth and in appointing their blue-eyed boys on every key position in almost every department including police.

Such has been the dismal performance of those who ruled the country from 2008-2013 that peace remained a far cry and even a comparison of the crime figures of this period with the last two years of Musharraf's dictatorial rule show the so-called democrats failing.

Crimes like gang rape, kidnapping for ransom, bank robbery and other heinous offences created unrest and sense of insecurity among the people of the country. According to the National Crime Data (NCD), total of 3,170,889 offences, including 456,552 against persons and 611,852 cases against property, were recorded during the last five years.

The NCD indicates that the crime in the country constantly increased with the average of 17.86 as compared to the figures of 2007 . The crime against person and property shows upward trend with the average of 24.12 as compared to the figure of 2007.

In 2007, 172,140 offences against person and property were recorded; in 2006 the number was 175,147 . While, 203,035 cases of the offences against person and property were recorded in 2008 with 17.94 increase; 205,259 cases in 2009 with 19.24 raise, 216,441 case in 2010 with 25.73 increase, 229,948 in 2011 with highest raise of 33.58 as compared to 2007 and 213,721 cases of against person and property were recorded with 24.15 increase, the NCD analyses said. It added that average increase of 18.74 was indicated in the offences against person and property as compared to figure of 2006 and 2007.

Although, the crime situation during Musharraf regime was not idyllic as the crime statistics till 2007 indicate but the democratic government failed to control the deteriorating situation of law and order.

A comparison between the average figure of yearly crime of the democrats and dictatorial regime indicates visible hike in heinous offences during the last five years. The 5-year crime 
statistics pointed out average increase of 27.53 during the democrat's rule, while, 18.73 rise in crime against person and property was seen.

Highest rate of kidnapping for ransom and commission of suicide, was recorded in Sindh during the last 5 years as 946 people were kidnapped for ransom which is 35.83 of the total offences, and 538 persons committed suicide as compared to 753 all over the country with the ratio of 71.44 in 5 years indicating that over 107 people chuck out their lives every year.

The Punjab contributed over 61.59 in the total crime, recorded throughout Pakistan during the last five years as 1,953,209 cases were reported in Punjab alone against 3,170,889 cases recorded all over the country

This study is an attempt to identify and examine the economic factors responsible for promoting crime in Pakistan. The main objective of the study is to analyze empirically the relationship between crime and major economic factors (unemployment, poverty and inflation) and to recommend policy measures to help \& check and prevent crime rate in Pakistan.

\section{Crime Rate in Pakistan}

Historically, the crime rate in Pakistan has been quite high since independence. The statistics reveal that total 73105 crime cases were registered in 1947, which doubled to 129,679 in 1971. There was a tragic increase in crimes after 1980 and the total reported crimes during the next decade (1980-90) were almost 403,078. This number reached to 438044 in 2007 (Gillani, Rehman and Gill, 2009). The annual growth rate of crimes is also increasing since 1951. The above mentioned figures are reveling reported crimes but the real picture cannot be drawn without inclusion of non-reported crimes in the country. The situation becomes more drastic if unreported crimes become part of crime statistics. About 30-50 crimes remain unreported in Pakistan generally (Gilanniet al., 2009).

Pakistan being a front line alien of the war against terrorism is experiencing adverse effects of global terrorism. Still majority of the population is illiterate. The unemployment rate is also high. Small scale enterprises are going to close due to terrible load shedding. Strong rooted religious extremism has created anarchy in society. Socio-political disputes are routine matters in rural and urban areas. Foreign debts are increasing and the value of the Rupee is declining rapidly. In view of above, the huge proportion of illiterate population has no clear guidelines about present and future career. So at the result of these social and economic factors they start to engage in the criminal activities.

\section{Objectives}

i. To identify and examine the social and economic factors responsible for promoting crimes

ii. To analyze the relationship between crime and major social factors (injustice, lawlessness and socialization) and economic factors (unemployment, poverty and inflation).

iii. To understand the conditions of prisoners in prison and behavior of jail administration towards them 
iv. To recommend some practical suggestions and rehabilitative measures after research to control that crime rate and to improve the conditions of prisoners

\section{Methodology}

Methodology can be described as a way through the research is conducted relevant literature about the topic. Different methods will be used for collect data, analyze data and interpret data. If literacy rate low then method will be used face to face interviews will suitable for collection data. Methodology comprises logical sequential steps through which the research plan or approach is implemented. It may refer to the philosophy of research process that includes the assumption or values that serves as the rationale for research. This methodology includes following stages.

\section{Hypothesis}

i. Illiterate people have more chances to involve in crimes

ii. A strong relationship $\mathrm{b} / \mathrm{w}$ absence of economic resources necessary for living and criminal activities

iii. Unemployment increases the chances to commit crime

iv. There is intimate relationship b/w Social factors (Social inequality / injustice / lawlessness) and Criminal behavior.

\section{Type of study}

Three types of studies present in social sciences: descriptive, casual, and exploratory. This research is basically descriptive, descriptive research involves collecting data in order to test hypothesis or answer question concerning the status of the subject of the study (Gay, 1996).The method of this quantitative research is "formal, objective, systematic process in which numerical data utilizes to obtain the information about the world" (burns and Cormack, 1991).

\section{Universe}

"Universe is defined as the total number of people living with in specific area" (Neuman, 2001). The selected universe for this study was conducted on peoples of Sargodha district. The 100 male's respondent are selected for this research from Sargodha district.

\section{Constraints}

There are some obstacles to not including the whole population in this research which are including the lack of resources, short time, lack of budget and inaccessibility's to the prisoners of whole and institutional long lasting and problematic process to access the prisoners.

\section{Sample size}

Data will be collected in district jail Sargodha. Data will collect through sample survey. Convenient sampling technique selected to collect data from district jail Sargodha because availability of restricted number of respondents and limited time period. The total sample size was consisting of 110 males.

\section{Instrument of the study}


Questionnaire was developing under the supervision of the advisor to find out the attitude of people. Questionnaire will develop on the basis of hypothetical frame work

\section{Data collection}

Social sciences deals with human being, which are most sensitive in nature .In such studies it is quiet essential that during development of measurement instrument, all aspects of data quality and human nature should be taken into account. Data collected through questionnaires which consist on close ended question.

\section{Testing of Hypotheses}

\section{Index Variable Construction}

To study the combine effect of all the variables in predicting the response variable all the statements in matrix questions are combined together to form a single prime or main variables known as index variable. However, before the development of index variable, it is pre-requisite to ensure the element of consistency among all the items in the matrix question. For this purpose, a reliability check is carried out and the value of Cronbatch Alpha is determined.

The Statistical Package for Social Sciences (SPSS) used to find Cronbatch Alpha values. During the reliability check, if the value of Alpha remains in the range 0.7 to 1.0 , because all items or statements or matrix questions are highly correlated and representing one idea. This facilitates the study of combine effect that otherwise is not possible.

On confirmation of element of consistency, the score on all the items in a matrix question recorded through response categories is summed up. The minimum and maximum value is determined through sub-menu descriptive statistics followed by frequencies. The next step the maximum and the remainder is divided with the number of descried level or categories in index variable. Now I will check my hypothesis after applying this method.

Hypothesis 1: Illiterate people have more chances to involve in crimes

Table 1: Association between education and crimes

\begin{tabular}{|c|c|c|c|c|}
\hline \multirow{2}{*}{ Education } & \multicolumn{3}{|c|}{ Criminal action } & \multirow{2}{*}{ Total } \\
\cline { 2 - 5 } & Murder & Robbery & Others & \\
\hline \multirow{2}{*}{ Illiterate } & 10 & 23 & 9 & 42 \\
\cline { 2 - 5 } & 23.8 & 54.8 & 21.4 & 100.0 \\
\hline $\begin{array}{c}\text { Under Matric, } \\
\text { Matric }\end{array}$ & 26 & 3 & 6 & 35 \\
\cline { 2 - 5 } & 74.3 & 8.6 & 17.1 & 100.0 \\
\hline $\begin{array}{c}\text { intermediate or } \\
\text { above }\end{array}$ & 18 & 6 & 9 & 100.0 \\
\hline Total & 54.5 & 18.2 & 27.3 & 110 \\
\hline
\end{tabular}




\begin{tabular}{|l|l|l|l|l|}
\hline & 49.1 & 29.1 & 21.8 & 100.0 \\
\hline
\end{tabular}

Chi-square $=26.928$ d.f. $=4$, P-value $=.000 * * * *=$ Highly significant

Table 1 presents the association between education of the respondents and their involvement in criminal activities. Chi-square value shows a highly significant association between education of the respondents and their involvement in criminal activities. Gamma value shows a negative relationship between the variables. So the hypothesis "Illiterate people have more chances to involve in crimes" is accepted.

Hypothesis 2: A strong relationship b/w absence of economic resources necessary for living and criminal activities

Table 2: Association between economic resources of the respondents and criminal activities

\begin{tabular}{|c|c|c|c|c|}
\hline \multirow{2}{*}{$\begin{array}{c}\text { Economic } \\
\text { pressures }\end{array}$} & \multicolumn{3}{|c|}{ Criminal action } & \multirow{2}{*}{ Total } \\
\cline { 2 - 5 } & Murder & Robbery & Others & \\
\hline \multirow{2}{*}{ Agree } & 14 & 2 & 3 & 19 \\
\cline { 2 - 5 } & 73.7 & 10.5 & 15.8 & 100.0 \\
\hline \multirow{2}{*}{ Neutral } & 14 & 9 & 7 & 30 \\
\cline { 2 - 5 } & 46.7 & 30.0 & 23.3 & 100.0 \\
\hline \multirow{2}{*}{ Disagree } & 26 & 21 & 14 & 61 \\
\cline { 2 - 5 } & 42.6 & 34.4 & 23.0 & 100.0 \\
\hline \multirow{2}{*}{ Total } & 54 & 32 & 24 & 110 \\
\cline { 2 - 5 } & 49.1 & 29.1 & 21.8 & 100.0 \\
\hline
\end{tabular}

Chi-square $=6.137$ d.f. $=4$, P-value $=.189 * * * *=$ Highly insignificant

Table 2 presents the association between economic resources of the respondents and criminal activities. Chi-square value shows a highly insignificant association between absence of economic resources necessary for living and criminal activities. Gamma value shows a positive relationship between the variables. So the hypothesis "A strong relationship b/w absence of economic resources necessary for living and criminal activities" is rejected.

Hypothesis 3: Unemployment increases the chances to commit crime

Table 3: Association between unemployment and Criminal activities

\begin{tabular}{|c|c|c|c|c|}
\hline \multirow{2}{*}{ Unemployment } & \multicolumn{3}{|c|}{ Criminal action } & \multirow{2}{*}{ Total } \\
\cline { 2 - 5 } & Murder & Robbery & Others & 19 \\
\hline \multirow{2}{*}{ Agree } & 8 & 8 & 3 & 100.0 \\
\cline { 2 - 5 } & 42.1 & 42.1 & 15.8 & 29 \\
\hline \multirow{2}{*}{ Neutral } & 18 & 7 & 4 & 100.0 \\
\cline { 2 - 5 } & 62.1 & 24.1 & 13.8 & 62 \\
\hline \multirow{2}{*}{ Disagree } & 28 & 17 & 17 & 100.0 \\
\cline { 2 - 5 } & 45.2 & 27.4 & 27.4 & \\
\hline
\end{tabular}




\begin{tabular}{|c|c|c|c|c|}
\hline \multirow{3}{*}{ Total } & 54 & 32 & 24 & 110 \\
\cline { 2 - 5 } & 49.1 & 29.1 & 21.8 & 100.0 \\
\hline
\end{tabular}

Chi-square $=4.853$ d.f. $=4$, P-value $=.303 * * * *=$ Highly insignificant

Table 3 presents the association between unemployment and Criminal activities. Chi-square value shows a highly insignificant association between unemployment and Criminal activities. Gamma value shows a positive relationship between the variables. So the hypothesis "Unemployment increases the chances to commit crime" is rejected.

Hypothesis 4: There is intimate relationship b/w Social factors (Social inequality / injustice / lawlessness) and Criminal behavior

Table 4: Association between Social factors and Criminal activities

\begin{tabular}{|c|c|c|c|c|}
\hline \multirow{2}{*}{ Social factors } & \multicolumn{3}{|c|}{ Criminal action } & \multirow{2}{*}{ Total } \\
\cline { 2 - 5 } & Murder & Robbery & Others & 55 \\
\hline \multirow{2}{*}{ Ngree } & 30 & 14 & 11 & 100.0 \\
\cline { 2 - 5 } & 54.5 & 25.5 & 20.0 & 27 \\
\hline \multirow{2}{*}{ Disagree } & 14 & 5 & 8 & 100.0 \\
\cline { 2 - 5 } & 51.9 & 18.5 & 29.6 & 28 \\
\hline \multirow{2}{*}{ Total } & 10 & 13 & 5 & 100.0 \\
\cline { 2 - 5 } & 55.7 & 46.4 & 17.9 & 100.0 \\
\hline
\end{tabular}

Chi-square $=6.616 \quad$ d.f. $=4$, P-value $=.158^{* * * *}=$ Highly insignificant

Table 64 presents the association between Social factors of the respondents and Criminal activities. Chi-square value shows a highly insignificant association between Social factors and Criminal activities. Gamma value shows a positive relationship between the variables. So the hypothesis "There is intimate relationship b/w Social factors (Social inequality / injustice / lawlessness) and Criminal behavior" is rejected.

\section{Findings}

i. Study findings shows that majority of the respondents have Ages between 26-35 years

ii. Study findings show that most of the respondents who did crimes are belongs to rural areas.

iii. Research findings shows that majority of the respondents were illiterate

iv. Study shows that most of criminals have higher family income.

v. Research findings shows that majority of the respondents are agreed that Socially isolate people mostly commit crime 
vi. Study reveals that majority of the respondents were strongly agreed with they are trapped by the mafia for crimes so it's a social factor

vii. Study shows that most of respondents were agreed that Lack of standard education is responsible for their crime

viii. Research reveals majority of the people are strongly agreed with that Lawlessness and anomic situation increases the ratio of crime day by day so it means that this social factors are responsible for crime

ix. Research shows that majority of the respondents were strongly agreed that Illiteracy is the main cause of crimes which is a socio-economic factor

x. Research result shows that majority of respondents were strongly agreed that Job dissatisfaction initiate them to do a crime"

xi. Findings states that majority of the respondents were strongly agreed that Aggression and exploitation are responsible for crime

xii. Findings shows that most of respondents were strongly agreed that Low education of people lead to crimes and that is also a social factor

xiii. Research shows that majority of the respondents were strongly agreed that Injustice is the cause of crimes as injustice is a social factor

xiv. Findings shows that most of the respondents were strongly that bad company leads to crimes

$\mathrm{xv}$. Research shows that majority of the respondents were strongly agreed that Situational factors are responsible for your crime

xvi. Results reveals that majority of the criminals were strongly agreed that Lack of job opportunity force people to commit crimes so it's a social factor that initiate to do a crime

xvii. Study findings shows that most of the respondents were strongly agreed that Poverty is the main cause of crimes

xviii. Study findings shows that a major proportion of the respondents were strongly agreed with that Disparity between the rich and the poor is responsible for the crime so it is an another social factor

xix. Findings shows that most of criminals were agreed that Inflation is the cause of crime

xx. Findings reveals that most of the respondents were strongly agreed with that economic pressure Lack of resources, unequal property distribution and to get high economic status encourage people to crime

xxi. Results shows a major proportion was strongly agreed that Weak structure of judiciary and administration promoted crimes and so social factor held responsible for crime 
xxii. Study shows that most of the respondents are using drugs in the jail.

xxiii. Findings shows that most of the respondents were disturbed from Congested environment of jail

xxiv. Research findings reveals that 38.6 of the respondents were satisfied with the jail management

xxv. Research findings reveals that most of the respondents were satisfied with the food service of the jail

xxvi. Research findings reveals that most of the respondents were satisfied with the police behavior towards them

\section{Conclusion}

It is impossible to be definitive about the causes of crimes. Crime is not caused by a specific, easily identifiable list of factors, but by the presence in a person's life of multiple risk factors (socially or economically) and the absence of protective factors in countering these. One thing that my research has shown is that there are conflicting views as to the motivations of crime and the influences on criminal behavior. Economic deprivation or poverty motivates individuals to commit crime or create the circumstances that serve as a breeding ground for crime, especially property crime in this research. Nevertheless, there are many who are poor but still choose to live a life of high moral standards and to adhere to societal norms. As such, poverty cannot be a lone explanatory variable for crime. Poverty will increase and the proportion of people who make significant income will decline .Socio-economic Factors including the immigrating poor, inflation, injustice taxation policies, jobs going overseas, illiteracy an increase in cost of living, and a reduction in consumer spending. Research concludes that majority of the respondents were satisfied with the jail management, food service of the jail and with the police behavior towards them but they were disturbed by the congested environment of jail.

\section{Recommendations}

The prevention of crime is a keystone requirement for a safe and secure society, the achievement of which is a prerequisite for sound economic growth through continuing business investment as well as community well-being and cohesion.

Evidence clearly shows that effective crime prevention initiatives can contribute significantly to the achievement of safe and secure societies. For example, along with many other Western developed countries, Australia has experienced significant declines in almost all categories of crime over the past decade.

The police alone cannot prevent crime, so government agencies, community groups, businesses and individuals need to combine their resources in an effort to avert a range of crimes before they happen. A combination of crime prevention effort targets crimes such as drug related crime, property crime, violence, robbery, vandalism, underage drinking, truancy and juvenile crime. So More social programs, subsidies, government housing, funded education, or 
community service programs only create more dependency on outside help. Politically, such programs are not widely acceptable because someone has to pay for those programs. Ultimately, if it were accepted that economic conditions are a causal factor for crime, then it will definitely get worse, as more people aided in the population and a higher proportion of the population are in the lower economic class.

Instead of discussing the causes of crimes, it is better to approach the issue by identifying the various risk factors for that initiating crime, and talk about the interventions that can either reduce those risks or increase protective factors in a person's life. It is also helpful in any discussion on the factors of crimes, to understand the main types of crimes. Interventions with criminal's onset must address, wherever relevant.

Finally, for making a crime free society it is very essential to build peace in the minds of people or inter and intra-personal level of peace should be develop that will only possible if role of law is established, equal resources, equal opportunities for all the people and government have policies to fulfill the basic essential needs of the people that are needed for the survival of people.

\section{References}

Agnew, R. (1999). A general strain theory of community differences in crime rates. Journal of Research in Crime and Delinquency, 36(2), 123-155.

Agnew, R., \& Brezina, T. (1997). Relational problems with peers, gender, and delinquency.

Alalehto, T. (2003). Economic crime: Does personality matter? International Journal of Offender Therapy and Comparative Criminology, 47(3), 335-355.

Baron W. S. \& Hartnagel F. T. (1997). Attributions, Affect and Crime: Street Youths'

Baron, S. W. (2004). General strain, street youth and crime: A test of Agnew's revised theory. Criminology, 42(2), 457-483.

Baron, S. W. (2008). Street youth, unemployment, and crime: is it that simple: Using general strain theory to untangle the relationship. Canadian Journal of Criminology and Criminal Justice, 50(4), 399-434.

Beck, T., Demirgüc-Kunt, A., \& Levine, R. (2006). Bank concentration, competition, and crisis: First results. Journal of Banking and Finance, 30, 1581-1603.

Buonanno, P. and Montolio, D. (2008) "Identifying the Socioeconomic Determinants of Crime across Spanish Provinces”. International Review of Law and Economics. 28(2): 89-97.

Considering Complexities in Understanding Youth Crime in Local Communities in Ireland. Irish Probation Journal, 6, 135-140.

Deller, S.C., Tsai, D. M. \&English,D.B.K. (2001).The role of amenities and quality of Life in rural economic growth. American Journal of Agricultural Economics 83: 352-365.

Dyfoos, J. G. (1993).Common Components of Successful Interventions with High-Risk Youth.in N.J. Bell and R.W. Bell (eds.), Adolescent Risk Taking (pp. 131-147), London: Sage 
Ehrlich, Isaac (1973), Participation in illegitimate activities: A theoretical and empirical Investigation. The Journal of Political Economy, Volume 81(3), pp. 307-322.

Flynn, N. (1996). Segregation and Crime: The effect of black social isolation on the rates of black urban violence. Louisiana State Univ. (USA). J. Social Forces, 76:4.

Gillani, M. S. Y., Rehman H. \& Gill A. R. (2009).Unemployment, Poverty, Inflation and Crime Nexus: Co-integration and Causality Analysis of Pakistan. Pakistan Economic and Social Review, 47(19), 79-98.

Gillani, M. S. Y., Rehman H. \& Gill A. R. (2009).Unemployment, Poverty, Inflation and Crime Nexus: Co-integration and Causality Analysis of Pakistan. Pakistan Economic and Social Review, 47(19), 79-98.

Hagan, J., \& McCarthy B. (1997).Mean Streets: Youth Crime and Homelessness. Cambridge: Cambridge UP.Hartnageul, F. T. (1998). Labor-Market Problems and Crime in the Transition from School to Work. CRSA / RCSA, 35(4).

Kufeldt, K. \&NimmoM. (1987a). Kids on the street they have something to say: Survey of runaway and homeless youth. Journal of Child Care, 3.53-61.

Logan, R. (1994).Living with Crime: The Implications of Racial and Ethnic Differences in Suburban Location. Social Forces. 73 (1), p395-434

Omotor, D. G. (2009) "Socio-Economic Determinants of Crime in Nigeria". Pakistan Journal of Social Sciences_6(2):54-59.

Schmitz, M. F. 2003. Influences of race and family environment on child hyperactivity and antisocial behavior. Marriage and Family; 65:835-849.

Sutherland, E. H. (1983). White collar crime. New Haven, CT: Yale University Fleisher, Belton M. (1966), the effect of income on delinquency. The American Economic Review, Volume 55(1/2), pp. 118-137.

Welish, J., Schmidt, F., McKinnon, L., Chattha, H. \&Meyers J. (2008).A Comparative Study of Adolescent.Risk Assessment Instruments, 15 (1), 104-115. 